\title{
Literary Lives
}

Founding Editor: Richard Dutton, Professor of English, Lancaster University

This series offers stimulating accounts of the literary careers of the most admired and influential Englishlanguage authors. Volumes follow the outline of the writers' working lives, not in the spirit of traditional biography, but aiming to trace the professional, publishing and social contexts which shaped their writing.

Published titles include:

\author{
Clinton Machann \\ MATTHEW ARNOLD \\ Jan Fergus \\ JANE AUSTEN \\ John Beer \\ WILLIAM BLAKE
}

Tom Winnifrith and Edward Chitham CHARLOTTE AND EMILY BRONTË

Sarah Wood

ROBERT BROWNING

Janice Farrar Thaddeus

FRANCES BURNEY

Caroline Franklin

BYRON

Sarah Gamble

ANGELA CARTER

Nancy A. Walker

KATE CHOPIN

Roger Sales

JOHN CLARE

William Christie

SAMUEL TAYLOR COLERIDGE

Graham Law and Andrew Maunder WILKIE COLLINS

Cedric Watts

JOSEPH CONRAD

Grahame Smith

CHARLES DICKENS

Linda Wagner-Martin

EMILY DICKINSON

George Parfitt

JOHN DONNE

Paul Hammond

JOHN DRYDEN

Kerry McSweeney

GEORGE ELIOT

\author{
Tony Sharpe \\ T. S. ELIOT \\ David Rampton \\ WILLIAM FAULKNER \\ Harold Pagliaro \\ HENRY FIELDING \\ Andrew Hook \\ F. SCOTT FITZGERALD \\ Mary Lago \\ E. M. FORSTER \\ Shirley Foster \\ ELIZABETH GASKELL \\ Neil Sinyard \\ GRAHAM GREENE \\ James Gibson \\ THOMAS HARDY \\ Linda Wagner-Martin \\ ERNEST HEMINGWAY \\ Cristina Malcolmson \\ GEORGE HERBERT
}

Gerald Roberts

GERARD MANLEY HOPKINS

Neil Roberts

TED HUGHES

Kenneth Graham

HENRY JAMES

W. David Kaye

BEN JONSON

R. S. White

JOHN KEATS

Phillip Mallett

RUDYARD KIPLING

John Worthen

D. H. LAWRENCE

Angela Smith

KATHERINE MANSFIELD 
Lisa Hopkins

CHRISTOPHER MARLOWE

Cedric C. Brown

JOHN MILTON

Priscilla Martin and Anne Rowe

IRIS MURDOCH

David Rampton

VLADIMIR NABOKOV

Peter Davison

GEORGE ORWELL

Linda Wagner-Martin

SYLVIA PLATH

Felicity Rosslyn

ALEXANDER POPE

Ira B. Nadel

EZRA POUND

Richard Dutton

WILLIAM SHAKESPEARE

John Williams

MARY SHELLEY

Michael O'Neill

PERCY BYSSHE SHELLEY

Gary Waller

EDMUND SPENSER

Tony Sharpe

WALLACE STEVENS
William Gray

ROBERT LOUIS STEVENSON

Lisa Hopkins

BRAM STOKER

Joseph McMinn

JONATHAN SWIFT

Leonée Ormond

ALFRED TENNYSON

Peter Shillingsburg

WILLIAM MAKEPEACE THACKERAY

William Christie

DYLAN THOMAS

David Wykes

EVELYN WAUGH

Jon Bak

TENNESSEE WILLIAMS

Caroline Franklin

MARY WOLLSTONECRAFT

John Mepham

VIRGINIA WOOLF

John Williams

WILLIAM WORDSWORTH

Alasdair D. F. Macrae

W. B. YEATS

\section{Literary Lives}

Series Standing Order ISBN 978-0-333-71486-7 hardcover

Series Standing Order ISBN 978-0-333-80334-9 paperback

(outside North America only)

You can receive future titles in this series as they are published by placing a standing order. Please contact your bookseller or, in case of difficulty, write to us at the address below with your name and address, the title of the series and one of the ISBNs quoted above.

Customer Services Department, Macmillan Distribution Ltd, Houndmills, Basingstoke, Hampshire RG21 6XS, England 


\section{Dylan Thomas}

\section{A Literary Life}

William Christie

Professor of English Literature, University of Sydney, Australia

\section{palgrave macmillan}




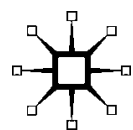

(c) William Christie 2014

Softcover reprint of the hardcover 1st edition 2014 978-1-137-32256-2

All rights reserved. No reproduction, copy or transmission of this publication may be made without written permission.

No portion of this publication may be reproduced, copied or transmitted save with written permission or in accordance with the provisions of the Copyright, Designs and Patents Act 1988, or under the terms of any licence permitting limited copying issued by the Copyright Licensing Agency, Saffron House, 6-10 Kirby Street, London EC1N 8TS.

Any person who does any unauthorized act in relation to this publication may be liable to criminal prosecution and civil claims for damages.

The author has asserted his right to be identified as the author of this work in accordance with the Copyright, Designs and Patents Act 1988.

First published 2014 by

PALGRAVE MACMILLAN

Palgrave Macmillan in the UK is an imprint of Macmillan Publishers Limited, registered in England, company number 785998, of Houndmills, Basingstoke, Hampshire RG21 6XS.

Palgrave Macmillan in the US is a division of St Martin's Press LLC, 175 Fifth Avenue, New York, NY 10010.

Palgrave Macmillan is the global academic imprint of the above companies and has companies and representatives throughout the world.

Palgrave ${ }^{\circledR}$ and Macmillan ${ }^{\circledR}$ are registered trademarks in the United States, the United Kingdom, Europe and other countries.

ISBN 978-1-349-45843-1 ISBN 978-1-137-32257-9 (eBook)
DOI 10.1057/9781137322579

This book is printed on paper suitable for recycling and made from fully managed and sustained forest sources. Logging, pulping and manufacturing processes are expected to conform to the environmental regulations of the country of origin.

A catalogue record for this book is available from the British Library.

Library of Congress Cataloging-in-Publication Data

Christie, William, 1952-

Dylan Thomas: a Literary Life / William Christie, Associate Professor, Department of English, University of Sydney, Australia.

pages $\mathrm{cm}$. - (Literary lives)

Summary: "Dylan Thomas: A Literary Life offers an accurate and unsensationalized account of the poet's life in the context of British and American literary culture in the first half of the twentieth century, along with a critical reading of a selection of characteristic works in the many different genres in which Dylan Thomas worked, from the dense and rhetorically powerful lyrics which established his reputation through his stories and radio and film scripts to the triumphant 'play for voices', Under Milk Wood. This study is designed to close what has been called 'the yawning gap' between Thomas's popular and critical reputations, and is a major contribution to the revival and revision of the poet's work and reputation" - Provided by publisher.

Includes bibliographical references and index.

ISBN 978-1-349-45843-1

1. Thomas, Dylan, 1914-1953.

century-Biography. I. Title.

PR6039.H52Z614 2015

$821^{\prime} .912-\mathrm{dc} 23$

2. Poets, Welsh-20th 
For Robert and Jan Jones,

Clive and Helen Woosnam, and all my friends in the

Dylan Thomas Society of Australia 


\section{Contents}

Acknowledgements viii

Preface $\quad$ ix

1 Uplands: Growing Up in Cwmdonkin Drive 1

2 Truant Years: Going (and Not Going) to School 19

3 'A Bit of a Shower-Off': Performing in Swansea 34

4 One-Track Mind: From Notebook Poems to 18 Poems 52

5 The Road out of Wales: Fame and Fitzrovia 72

6 'From Love's First Fever': Love and War, Guile and Beer 92

7 'A Crucial Point in His Career': Reinventing Dylan Thomas 110

8 'Radio's a Building in the Air': Lord Cut-Glass, Poet of the Airwaves 126

9 'My Seashaken House on a Breakneck of Rocks': The Road to Laugharne $\quad 140$

10 'O My America! My New-Found-Land': The Poet on Tour

11 The Road to Milk Wood 173

$\begin{array}{ll}\text { Epilogue } & 191\end{array}$

$\begin{array}{lr}\text { Abbreviations } & 193\end{array}$

$\begin{array}{ll}\text { Notes } & 194\end{array}$

$\begin{array}{ll}\text { Bibliography } & 214\end{array}$

$\begin{array}{ll}\text { Index } & 218\end{array}$ 


\section{Acknowledgements}

The reader will quickly realize how indebted this account is to Dylan Thomas's many biographers, but four stand out and should be named here: Constantine Fitzgibbon, Paul Ferris, James A. Davies, and Andrew Lycett.

After that I wish to express my gratitude to the staff of the Harry Ransom Center at the University of Texas, Austin, and the State University of New York, Buffalo, for their unfailing kindness and assistance during a brief visit last year.

Apologies and gratitude to my wife, Patrice, for putting up with my obsessions and absences must be starting to wear a little thin, but as Thomas said when he offered his Collected Poems 'for the love of Man and in praise of God', well, 'I'd be a damn' fool if I didn't'.

Finally, for their good fellowship over many years, I am indebted to the Dylan Thomas Society of Australia, collectively and individually, to whom I have dedicated this book. 


\section{Preface}

'NO ONE can deny that the most attractive figures in literature are always those around whom a world of lies and legends has been woven', wrote the seventeen-year-old Dylan Thomas while a cadet reporter on the South Wales Evening Post:

those half mythical artists whose real characters become cloaked for ever under a veil of the bizarre. They become known, not as creatures of flesh and blood, living day by day as prosaically as the rest of us, but as men stepping on the clouds, snaring the world of beauty from the trees and sky, half wild, half human. ${ }^{1}$

Lies and legends variously attest to the half wild, half humanity of Thomas himself, the notorious drunkard who reputedly sank eighteen straight whiskies on his deathbed, the flouter of social convention and literary orthodoxy, the 'man whose work' - like that of his character, Tom Agard - was 'a studied insult to all academic balderdash', ${ }^{2}$ and the expansive 'lover of the human race, especially its women'. 'A chronic liar', his 'disorderly style of living makes good copy by itself. He lived, looked and sounded like the popular idea of the poet, with recognisably poetic poems to show for it; and if there were fears and empty spaces in his life, he concealed them with bizarre language and behaviour' - though not nearly as often as this biographer, Paul Ferris, implies. ${ }^{4}$ William Connor's tribute to the poet as an archetypal, arguably comic-book Romantic in the London Daily Mirror was not uncommon at the time of the poet's death:

Dylan Marlais Thomas, poet, roisterer and lover of mankind, had the divine flash within him. Not for him the bloodless world of slide rules and isotopes; not for him the clinical detachment of frosty reason.

Thomas - fierce, fine, and foolish Thomas had hotter fires to stoke and brighter flames in which to consume himself. ${ }^{5}$ 
Nor was it confined to the popular press. The eccentric society poet, Edith Sitwell, gave us a similarly exaggerated portrait of Thomas as a latter-day druid, chanting from the bowels of the earth:

This condensation of essence, this power of 'becoming a tree', is one of the powers that makes Mr. Thomas the great poet he is. His poems appear, at first sight, strange. But if you heard a tree speak to you in its own language, its own voice, would not that, too, appear strange to you? ${ }^{6}$

If you heard a tree speak to you in its own language? Dylan Thomas the tree?

Whatever label may have been attached to Thomas, it was tacitly accepted that he took his place in a Romantic or 'enthusiastick' tradition, part of a movement 'away from a conscious and intellectual style of writing towards the involuntary, the mysterious, the wordintoxicated, the romantic and the Celtic', to quote Stephen Spender. Thomas, for Spender, is 'a "bardic" poet', 'an elemental writer dealing with ideas and images which seem on the verge of disintegrating into a formless chaos'. ${ }^{7}$ To his acolytes, he was the celebrant of a primitive nature. In the first book-length survey of Thomas's work, Henry Treece confidently borrowed a phrase about Gerard Manley Hopkins when he described what he took to be the intoxicated rush of Thomas's poetry as 'a passionate emotion which seems to try to utter all its words in one'. ${ }^{8}$ To his detractors - like Geoffrey Grigson, and there have been many more since Grigson - it was fatuous, esoteric babble. But to Grigson as well, Thomas was an 'exemplar' of the 'new romanticism' - most Romantic of all, perhaps, in encouraging the type of critical comment that slides indiscriminately from talking about poetry into talking about the poet. ' Amid the social and political preoccupations of the 30's', wrote Herman Peschmann looking back thirty years later, 'Dylan Thomas's work, the highly personal utterance of a Romantic visionary, had been a lone voice'. ${ }^{10}$ 'After the hiatus created by high Modernism', writes David Perkins, 'the history of modern poetry is in part the story of a reconnecting to Romantic roots':

A 'Neo-Romantic' style developed in England during the 1930s and was briefly ascendant during the 1940s. Dylan Thomas was its 
major poet. 'Romantic' was the word that was used at the time, and implied that the Neo-Romantics were challenging the high Modernism of the 1920s and the discursive, intellectual styles of the 1930s. Thomas was typical in this respect. He had the mystical intuitions, emotional intensity, personal utterance, and natural imagery of a poet in the Romantic tradition. ${ }^{11}$

Perkins's scare quotes, however, give it away. 'In the same poems', as he himself admits, Thomas 'was also a poet of Metaphysical wit and Symbolist technique'. With Claud Rawson, Perkins might have added the very different, scabrous wit and satirical verve of Augustans like Swift and the Pope of The Dunciad, also identifiable in Thomas's poetry. ${ }^{12}$ There is more to Thomas's poetry and prose, and more to Thomas himself, than the easy labels 'Romantic' and 'Neo-Romantic' suggest (just as there is a good deal more to the Romantic poets than the use of the label usually implies).

Two literary historical confusions, aided by Thomas's own seemingly anarchic lifestyle and equivocal posturing, contributed to what has proven to be a resilient misrepresentation, both of the poet and of his poetry. The first was his association with the Apocalyptic movement set up by Henry Treece in the late 1930s, which for a short period extolled Thomas as its high priest:

the writer who senses the chaos, the turbulence, the laughter and the tears, the order and the peace of the world in its entirety, is an Apocalyptic writer. His utterances will be prophetic, they will tend to be incantatory, and so musical. At times, even, the music may take control and lead the writer from recording his vision almost to creating another vision. So, momentarily, he will kiss the edge of God's robe. ${ }^{13}$

A glance at Thomas's earlier poems seems to confirm this preoccupation:

And death shall have no dominion.

Dead men naked they shall be one

With the man in the wind and the west moon;

When their bones are picked clean and their clean bones gone, 
They shall have stars at elbow and foot;

Though they go mad they shall be sane,

Though they sink through the sea they shall rise again;

Though lovers be lost love shall not;

And death shall have no dominion. ${ }^{14}$

The identification was only confirmed by Thomas's providing poems for the magazine Apocalypse. As the following extract from 'Picasso for Guernica' by the Apocalyptic poet J.F. Hendry suggests, the rhetorically energetic but unintelligible utterance, the violence and anatomical imagery, and some of the verbal habits of Thomas's poetry (in the compound 'mantrump' and 'rubble-teat', for example) continued to affect the poetry of the 1940s:

Splint for the shriven fear I foster mantrump out

Of festered history; sprout pointed fingers

Where an after birth is dung and rubble-teat.

I am the eyeball blown world! Axis of anger!

Along with bringing down on Thomas the opprobrium of conservative forces within the social and literary establishment - after all, 'the single most popular poem of this period, and of the century', as Chris Baldick reminds us, "was Rudyard Kipling's "If_-"'15 - the association of Thomas and the Apocalyptic movement became the subject of an infamous hoax in Australia and beyond, in which the poets James McAuley and Douglas Stewart composed a set of pretentious and impenetrably difficult lyrics by a dead poet whom they named Ern Malley, recently deceased. Before being revealed to be a hoax, the poems (like this one, entitled 'Sweet William') were greeted with often rapturous applause:

I have avoided your wide English eyes:

But now I am whirled in their vortex.

My blood becomes a Damaged Man

Most like your Albion;

And I must go with stone feet

Down the staircase of flesh

To where the shuddering embrace 


\begin{abstract}
My toppling opposites commit
The obscene, the unforgivable rape.

One moment of daylight let me have

Like a white arm thrust

Out of the dark and self-denying wave

And in the one moment I

Shall irremediably attest

How (though with sobs, and torn cries bleeding)

My white swan of quietness lies

Sanctified on my black swan's breast.
\end{abstract}

'In style', wrote McAuley and Stewart, the poems were to imitate 'the whole literary fashion as we knew it from the works of Dylan Thomas, Henry Treece and others' ${ }^{16}$ To this day, no one is quite sure what to do with 'Ern Malley's' poetry, and there is still strong support for taking them seriously as poems, in spite of their burlesque origins. For our purposes, what the hoax amounts to is a sensational episode in the protracted critical and cultural battle over just how seriously to take Thomas's early poetry.

All in all, it can be understood why, as the Apocalyptic Henry Treece later recalled, Thomas 'was the obvious focal point for such a movement'. ${ }^{17}$ Thomas himself, however, was adamant: 'I won't sign, with or without argument, the Apocalyptic Manifesto', he told Treece, 'I agree with and like much of it, and some of it, I think, is manifestly absurd' ${ }^{18}$ But the association, complicated by a flirtation with Surrealism similarly disavowed by the poet, lasted just long enough to forge a connection that would persist and for Thomas to have been held responsible for many of the literary affectations of the 1940s.

The second literary historical factor involves the later stage of Thomas's career. As with the Great War, the Second World War encouraged a number of poets to return to nature for their subject matter and sanity, and Thomas went with them. Though, as Barbara Hardy has said, 'there are few of Thomas's poems which do not offer a meditation upon nature ${ }^{\prime 19}$ - or, at least, few which do not involve an elemental natural or physical imagery - his work showed a marked shift during the war towards a more recognizably natural world, celebrated in the wake of the Blitz and the atom bomb, as well as a marked shift towards his own Welsh childhood. In 'Poem in 
October', 'Fern Hill', and the incomplete In Country Heaven sequence, Thomas dispenses with the violence and compression, and much of the obscurity, of his earlier poetry. While Thomas makes little attempt to develop his personal vision and memories of childhood into psychological and philosophical convictions - as Wordsworth, for example, had done - the shift in style and accessibility is marked, as Thomas's idea of nature swerves towards what, as a young man, he had disparaged as 'hedgerow' poetry: 'leaning over some country stile with placid expression, thinking of nothing more edifying than the brevity of life, and the inanity of personal expression' ${ }^{20}$

On top of this, Thomas is probably the most recited and recorded twentieth-century poet in the English language, giving the poet a celebrity almost uniquely allied to the relatively new media. (Thomas even made a single appearance on television before his death.) Whether peculiarly Welsh or just plain idiosyncratic, Thomas's preoccupation with words as sounds and with poetry as performance 'A poem on the page', he argued, 'is only half a poem'21 - has become as legendary as his drinking habits and womanizing.

Since his death, the popular image of Thomas as archetypal Romantic - whether deracinated bohemian or Welsh bard - has been propagated and perpetuated by the culture industry which adopted him towards the end of his career, and it remains a feature of the poet's posthumous existence in the media and the popular imagination. As well as involving a radical misreading of his poetry and its significance, this popular image of Thomas involves a radical simplification of a conflicted but often astute human being, a simplification that ignores the complicated, sceptical attitude the poet adopted towards his own ideas and experience. Thomas laboured 'intensively over the intricate craft of poetry', in search of what he called (both ironically and ingenuously) 'the accident of magic', 22 creating verbal and aural intricacies that are by no means always shallow and self-defeating, nor always self-indulgent exhibitionism. And his reading amongst the poets, though haphazard (which poet's is not?), was wide - much wider, certainly, than has been acknowledged by the popular press. Amongst the canonical poets, Shakespeare, Donne, Herbert, Blake, Hopkins, Hardy, Owen, Yeats, Lawrence, and Osbert Sitwell stand out (in spite of his occasional disavowal of any one or all of these), amongst the prose writers Dickens and (pre-eminently) Joyce, and this does not include his familiarity with an impressive 
range of less canonical twentieth-century writing, some of it now forgotten by us, but recoverable from literary magazines, his poetry reading lists, and radio broadcasts. For all this reading, however, he is (to quote Constantine Fitzgibbon) 'a poet as consciously and deliberately original' as any poet who has ever written. ${ }^{23}$ Many of Thomas's best poems result from a metaphysical wit that remains too rarely recognized and a self-scepticism that gave him shrewd insight. Before anything else, Thomas was a writer in love with language and literature and his work betrays a verbal and prosodic vigour and inventiveness that is rare in the Anglophone literary tradition. He was also, in both his life and his writing, in love with excess, though that makes his writing much harder to characterize and talk about than his life. 'No modern poet', as Paul Ferris has said, 'has generated so much criticism, gossip, reminiscence and biography'. ${ }^{24}$

Thomas lived by his wits and his words, as literary a life as that of anyone else who has ever lived, but a literary life of Thomas needs to rescue the literature from the gossip, to recover his literary priorities, and to narrow what John Goodby calls 'the huge gap between the popular and academical-critical reputations' ${ }^{25}$ At the same time, of course, it needs to position Thomas, firstly, within the social and institutional context of his aspiring parents' rural and suburban Wales and, secondly, within the literary institutions of his period: the little magazines, the literary prizes and patrons, the London publishing houses, the BBC, all of which both enabled and inhibited the formal and expressive possibilities available to the poet. Some of these eleven chapters are dedicated as much to an aspect of Thomas's work - poetry, letters, fiction, radio features, documentaries, film scripts, Under Milk Wood - as they are to a specific period of the poet's life, so that while discussion of the poet's life is fairly strictly limited in any one chapter, Thomas's engagement with one or other aspect of literature and literary culture will in some cases be found to extend beyond the chronological boundaries of an individual chapter. 